\title{
E-COURSE MANAGEMENT WITHIN MOODLE IN HIGHER EDUCATION: TECHNOLOGICAL AND PEDAGOGICAL ISSUES
}

\author{
E-studiju kursa vadīšana Moodle sistēmā augstākajā izglītībā: \\ tehnologiskie un pedagogiskie jautājumi
}

\author{
Imants Gorbāns \\ University of Latvia \\ Jekaterina Bierne \\ University College of Economics and Culture
}

\begin{abstract}
E-course management could be reflected both pedagogically, which implies analysis of teacher's role as course manager, and administratively, making course activities traceable for estimation and institutional control. The article presents the results of Moodle log data analysis at higher education institutions in Latvia. Analysis is made in order to reveal Moodle log data opportunities and restrictions as an instrument, which could be purposefully used for course management both in administrative and pedagogical sense. Moodle log data analysis, which is showing time, activities and additional information about Moodle interactive tools usage, has been compared to teachers' self-report survey results about their e-course management activities within Moodle. The study shows that teachers are tended to overestimate their course management activities' frequency within Moodle comparing to lag data. Possibility to analyse Moodle log data by teachers and higher education institution administration could help to improve e-courses management, which is significant factor for improving learning outcomes.
\end{abstract}

Keywords: E-course management, higher education, Moodle log data, interactive learning, pedagogical innovation

\section{E-course Management issues in the context of virtual learning in Latvia}

Knowledge based society focuses on enabling person to have greater use on technological informational opportunities. Moodle is such an opportunity itself and enables teachers and students to collaborate and create interactive learning environment which produces knowledge effectively. Initializing of Moodle platform usage in Latvian higher education institution typically takes place order to offer additional educational options and to preserve competitiveness at higher education market (Birzina, 2012). For now Moodle are using such Latvian higher education institutions as University of Latvia, Riga Technical University, Daugavpils University, Latvia University of Agriculture, Riga International School of Economics and Business Administration, Ventspils University College, University College of Economics and Culture, Information Systems and Management Institute etc. There are different models of using Moodle platform within Latvian higher education institutions: as supportive instrument within blended learning or as main instrument in distance learning. The concept 
of e-learning in Latvia is used as a general term reffering to all forms of teaching and learning, where information and communication technologies are involved, and relating to such terms as distance education, blended learning (combination of distance and face to face learning), online learning, virtual learning, webbased learning. Providers of distance learning can raise their competitiveness among the other suppliers of adult education because of its flexibility. But for now blended learning are mostly implemented in higher education in Latvia. Ecourses are usually combined with traditional face to face acitivites and, when offered, in most cases are used as suppementary part to traditional studies (Birzina, 2012).

In previous studies concerned with virtual learning environment (VLE) in higher education institutions in Latvia and Lithuania mostly such issues as digital literacy (Birzina, 2007; Ivanova, 2009; Vronska, 2012) and modernization of studies with choosing and integrating different information and communication technologies (Miķelsons un c., 2005; Gorbāns, 2008, 2011; Paulins, 2010; Kankevičiene, 2012) were highlighted. But there are some other challenges in the realm of higher education modernization with Moodle in Latvia. One of them connected to fact, that Moodle implementation typically was taking part just as additional option with no especial requirements for expected performance, clearly formulated strategy or criteria for its usage assessment. It was closer to celebrated initiative then definite framework, thus managerial issues of VLE both in technical and pedagogical sense usually were no especially formulated, neither systematically studied. As a result many Latvian higher education institutions are having Moodle practice, developed in their own mode and more or less successfully tailored for their educational needs, but no clear analytical approach to its management, assessment and further development. On the other hand, these issues will unavoidably become topical in the nearest future, for Ministry of Education is ready to announce effective usage of e-learning environment as one of higher education institution assessment criteria. The chapter "Change of Paradigm in Education (2010)" of the document "Sustainable Development Strategy of Latvia until 2030" published by Saeima of the Republic of Latvia mentions, that in addition to the usual study process, educational institutions should create distance learning programs using e-technologies. It is mentioned, that in case of higher education institutions programs may take place mainly in e-learning environment. That means, that e-course management issues will become increasingly topical. Ideas and possible criteria for "good practice in e-learning" are discussed in Latvia for some years (Slaidiňš, 2005), but there are few empirical studies, which are focused on its implementations at least in partial aspects (Misnevs, 2010; Maslo, Fernandez-Gonsalez, 2012; Birzina, 2012). While there is no uniform state system to monitor and coordinate e-learning in Latvia, monitoring and managing e-learning system it is actually an issue for each concrete deliverer of it. Management of e-program is unthinkable without properly resolved e-course 
management. Taking into account that all mentioned higher education institutions are using Moodle platform for such needs, it could be expected, that pedagogical and technological issues of e-course management within Moodle could be one of the most topical in e-learning in Latvia.

The representation of what is e-course management to some extent varies in different sources. One of these representations is much more administrative and institutionally oriented than pedagodical and educationally focused (Khan, 2005). From this viewpoint, Moodle usage in higher education institution is considered in the terms of human resources involved the e-learning content development process and maintenance of online course offerings, technology requirements, timelines, security, administrative services, copyright coordination. From another viewpoint, defining Moodle as „course management system" (Hollowell, 2011), such more pedagogical aspects as instruction, tutoring, assistance, discussions moderation or facilitation, learning objects adjustment and updating are highlighted. Both approaches include monitoring of e-learning environment. Tracking students and teachers activities in online course management system is important both administratively for higher education institution evaluating quality of e-learning process, and pedagogically for teachers themselves in order to reflect on their professional performance. There are only some points, which could be achieved by this mean. When students and teachers interaction realizes by the means of technological tools and can be shown as a log of definite activities usage, making it traceable and measurable, it reveals some gaps between desirable situation and real educational practice.

\section{Pedagogical Issues of E-course Management}

ICT usage in educations and learning within virtual settings including Moodle contribute to changes in teacher role (Green, Edwards and al., 2010). When teacher encounters requirement to transform the traditional course into e-course, this is not only tools and content transformation but teacher's role as well. Teacher's activities as a course manager are traceable with the help of Moodle data log. If teachers have access to these data, they as the course managers have possibility to reflect on their own activities as well as students' activities within course. But teachers' access to this data is a very rare case. System administrator of institution and sometimes e-program coordinator are having such access, but they are not processing these data at least in the mode that could help teacher to reflect on e-course activities and to make some pedagogical conclusions. There are some researches considering possibility to use Moodle log data for understanding pedagogical issues, such as collaborative learning behavior $(\mathrm{Lu}$, Law, 2012) at least in some partial aspects, as using definite tools within definite projects. But these data could be used in more general way in the higher education institution practicing e-learning with Moodle. Some possibilities for e- 
course management analysis in the interests of educational institution administration as well as teacher may derive from such simple Moodle log parameters:

1) Time - allows analysis of learning activities from the viewpoint of frequency and regularity. It may help to derive some conclusion about motivation, complexity degree or understanding difficulties (for instance, number of continuous unsuccessful attempts to cope with the task in short period of time), teacher's responsiveness and some other aspects;

2) IP address - shows where from definite activities are coming, what could be important in the case of tests (for example, possibility to see, that the test was filled for two times from the same IP address, causing grounded suspicion about the same person filling it next time in the place of another person);

3) Action - shows type of activities (viewing or adding definite resources and assignments, quiz attempting and reporting, posting at forum, grading, course updating), which could be used for different types of analysis;

4) Information - showing additional comments to action.

Moodle 2.2 e-course log file tool view as teacher may see it, is given the Figure 1.

\section{DatZ1026 : Datorsistēmu uzbūve I: Imants Gorbāns, Visas dienas (Server}

\begin{tabular}{|c|c|c|c|c|c|}
\hline \multirow[t]{2}{*}{ DatZ1026 : Datorsistēmu uzbūve I v } & \multirow[t]{2}{*}{ Imants Gorbāns } & Visas dienas & \multicolumn{2}{|r|}{$\checkmark$} & Visas aktivitātes \\
\hline & & Rādit lapã & $\checkmark$ & Iegūt šo & žurnālus \\
\hline
\end{tabular}

3967 ierakstu rādīšana

Lapa:(Iepriekšējais) $123456789101112131415161718 \ldots . .40$ (Nākamais)

\begin{tabular}{|c|c|c|c|c|}
\hline Laiks & IP adrese & Pilnais nosaukums & Darbība & Informācija \\
\hline Pk 2013. gada 18. janvāris, 11:12 & $21 \quad 7=$ & Imants Gorbāns & calendar edit & Tests Nr. 4 - Datorsistēmu uzbūves teorē \\
\hline Pk 2013. gada 18. janvāris, 11:12 & 21 & Imants Gorbāns & course update mod & quiz 4394 \\
\hline Pk 2013. gada 18. janvāris, 11:12 & 21 & Imants Gorbāns & quiz update & Tests Nr. 4 - Datorsistēmu uzbūves teorē \\
\hline Pk 2013. gada 18. janvāris, 11:11 & $21=$ & Imants Gorbāns & quiz view & Tests Nr. 4 - Datorsistēmu uzbūves teorē \\
\hline Pk 2013. gada 18. janvāris, 11:11 & $21 ?=4$ & Imants Gorbāns & quiz view all & \\
\hline Pk 2013. gada 18. janvāris, 11:11 & $21+$ & Imants Gorbāns & course view & DatZ1026 : Datorsistēmu uzbūve I \\
\hline Pk 2013. gada 18. janvāris, 11:11 & 21 & Imants Gorbāns & calendar edit & Tests Nr. 3-b - Skaitišanas sistēma \\
\hline
\end{tabular}

Figure 1. Moodle 2 log file tool view of teacher activities in current e-course

Figure 1. shows log file about teacher activities with detailed records. After 40 pages of $\log$ file general amount of activities during the semester can be measured. It is important that server administrator had configured log rotation in accordance with the educational interests and log files kept at least one full semester including session. Thus it is possible to analyze users' activities and to 
make some conclusions for course further developments as well as for pedagogical practice improvement in virtual learning environment.

In this pilot research in two Latvian higher education institutions Moodle log data analysis for the 2012 October - 2013 February was conducted mostly for parameters of time and action, as well as survey of 55 teachers of the same institutions in order to self-report some activities in e-learning environment. Each survey was individually matched to Moodle log data. Most interesting and controversial results of the study are shown in the Table 1. and Table 2.

Table 1

Course Forums Usage Frequency by Teachers Survey and Moodle Log Data

\begin{tabular}{|l|c|c|}
\hline Period & By survey & By log \\
\hline Never & 21 & 31 \\
\hline Every day & 1 & 0 \\
\hline Once 3 days & 6 & 2 \\
\hline Once a week & 12 & 6 \\
\hline Once 2 weeks & 10 & 4 \\
\hline Once a month & 5 & 5 \\
\hline Once a semesters & 0 & 7 \\
\hline
\end{tabular}

Table 1. shows, that teachers are tendend to overastimate their communicative activity frequency using such Moodle tool as Forum. Teachers, who were using Forum actually once a semester reported, that it is done once a month. Some teachers, who were making posts once a month reported, that they are doing it once a two week. 10 teachers, which were never using Forum in examined period of time still reported, that they are doing this. It could be interpreted as kind of self showing and approving as modern teacher at least minimally communicating with students this way. It could be interpreted as well as element of social desirability and wishing to meet education institution and students expectatons as communicative teacher. Possibly, it is hard for teacher to recognize that nothing is done for this period of time in the sense of making course more social. At the same time, such ,illusuion” could be sign of positive intent to use Moodle communicative tools more in future, than that is taking part now. Interesting, that answering the question „What for you are using Forum?" 21 teachers reported, that are doing it in order to comment appointments and requirements $(10$ - to explain difficult content, 12 - to announce changes and updates in the course; question format allowed checking all appropriate options). That leads to supposition, that some traditional courses are not modified enough into e-courses for the case of distance learning. The same formulations of assigments and reguirements are put into e-environments as its are discribed in curriculum. In the traditional educational settings these assignments and reguirements get clarified and repeatedly anounced with additional comments in 
the calssroom. But virtual settings needs transformated formulations, possibly additional examples, which are clarifying teacher's expectations.

Table 2

\section{Maximal Period of Students Waiting for Teachers Response by Teachers Survey and Moodle Log Data}

\begin{tabular}{|l|c|c|}
\hline Period & By survey & By log \\
\hline $24 \mathrm{~h}$ & 1 & 1 \\
\hline 3 days & 24 & 12 \\
\hline Once week & 19 & 14 \\
\hline Two weeks & 5 & 9 \\
\hline Month & 5 & 8 \\
\hline 6 weeks & 1 & 5 \\
\hline Two months & 0 & 4 \\
\hline Till the end of semester & 0 & 2 \\
\hline
\end{tabular}

Table 2. is showing picture with the same tendency as Table 1 . While log data show that 12 teachers are typically responding in 3 days, number of teachers, who reported such practice in survey are twice as much. While log is showing, that some teachers are actually non-responding, no one teacher reported that in survey. The nature of this partial non-match could be psychological and combining self approving, social desirability, distorted reflection of activities during the whole semester, and even the result of institutional pressure expecting teacher to use Moodle actively. This is sensitive issue that could be studied deeper in future. Survey responses are tended to "glide" in the sense of number to the higher frequency, than objective Moodle log data. It may be showing teachers' readiness and for the moment still unrealized intent to become more responding in future. It should be mentioned, that these two tables is a result of detailed and time consuming work with course logs in order to trace user's activities from the time and activities perspective. This means that definite method is needed to simplify this task in order to process log data for analytical representation in the interest of higher education institution and teachers themselves. There are some other specific issues shown in the teachers' survey. 48 from 55 teachers reported, that had not received sufficient training on how to manage e-course. That could be due to institutional and educational accenting of course creation and development issues preparing teachers to working with Moodle, more than course deliverance and managing issues. The main institutional priority in this period was to start e-learning programs and to engage teachers in them. Now it could be expected, that teachers are ready to have advanced Moodle courses in order to improve course management skills.

Specific course management questions, such as "Is it specified in your e-course, how much time approximately could take for student to complete each appointment?" (10 - yes; 12 - no; 28 - partly; 5 - not needed) or "What are you 
doing to prevent course content outdating?" (32 - revising it twice a year, 17 attaching new sources of information; 13 - revising focus of appointments, 8 other; question format allowed checking all appropriate options), shows that teachers are ready to improve course management and accepting their role of not only course creator, but deliverer and manager as well.

Specific institutionally oriented questions showed that many teachers (29) are not really sure, if there is key person in the institution involved in day-to-day activities of the e-learning or which is this position in their institution. The same picture shown with the question "Does the institution have a system/framework to recognize the degree of dedication in teaching e-course among academic staff?" (34 - I'm not sure, 16 - no). This means that probably comprehensive administrative and supportive framework is lacking at the present moment at the studied institutions.

Answers to the question "Are there clear expectations in your e-course for students about Moodle activities usage?" showed, that clearest expectations are formulated towards tests (quiz) and assignments (almost in all cases), 12 teachers mentioned Forums usage, no one mentioned workshops and data bases, but in 2 cases wiki tool was mentioned, which according to log data in this study was not used at all. This makes to conclude, some interactive and more complicated Moodle tools are rarely used, possibly, because teachers are not prepared enough, but in some cases it is possible, that teacher don't fully recognize used Moodle tools or just made error while answering the survey questions.

Such questions about course managements as "Are you checking, how often student is visiting your e-course?" (30 - no, 26 - I don't know how to do this), "Do you check, if students are viewing/downloading attached sources (articles, presentations etc.)?" (26 - I don't know how to do this; 18 - no) show that teachers are not using Moodle log data to reflect on their and students' activities. They mostly don't have access and don't fully recognize its options. Producing useful methodology for Moodle log data analysis could be very actual for all higher education institutions using Moodle. Methodology of management of electronic educational resources still is not developed enough to ensure high level of its effective implementation in all cases, whe institution needs that. To some extent this could be formulated as deficit of clear reasons to develop such methodology, because there were no definite expectations from higher education institutions about measurably effective usage of virtual learning environments.

\section{Technological Issues of E-course Management}

Moodle is the most popular of the free e-learning systems, the level of IT use Open Source Software, Open Standard. It is modern, contemporary, innovative learning environments, which is close to students with its similarity to well known social networks. Usually Moodle implementation includes such major 
steps as Moodle server installation, planning Moodle deployment, creation of course categories and courses, creation of groups of students (classes), upload users or syncronise with user database server. For instance, at the University of Latvia it's information system LUIS loguins are used (http://estudijas.lu.lv), but professional schools of Latvia implement users synchronization with e-journal Mykoob, thus Moodle users at these schools log in with existing e-journal log (http://profizgl.lu.lv/mod/forum/discuss.php?d=764). Next steps are system testing, informing users about the system, access and technical support, elearning start-up content creation by teachers and users training (both teachers and students). It is essential to add to these usual steps such elements as users continuous support (both technical and pedagogical), internal assesment in order to motivate users and to monitor Moodle system usage activites, technical and pedagogical corrections relevant to identified problems, teachers further education (at the professionals schoolf of Latvia positive interest is shown towards advanced Moodle techniques acquisition.

One of the most important aspects in ensuring Moodle qualitative usage and effective course management are users' motivation and their activity analytical monitoring and control. If right from the start academic staff typically perceives e-learning implementation with restrain, then by the time appears positive attitude and enthusiasm, as it was shown in ESF un University of Latvia professional schools' project „Competence enhancement of general subjects' teachers, engaged in professional education" could be mentioned. Main problems which are highlighted both in discussions and professional school teachers' survey are:

1) lack of digital literacy and developed ICT skills, which is especially disturbing some older teachers and makes them feel insecure working with computer in general;

2) anxious attitude to teaching and learning process transparency and controllability, ensured by ICT options such as data log;

3) need to restructure curriculum and teaching techniques due to such educational technology s Moodle. One of the biggest problems for teachers who practice the old lecture style teaching, using written and often significantly outdated synopsis, is that when these course basic synopsis is put in Moodle, students will no longer have reason to come to the lectures. This problem connected to the challenging task to improve the course, to change teaching technique, to stimulate active learning, to create room for practice and discussion in the case of blended learning;

4) fear that well-developed e-course makes teacher unnecessary element od teaching-learning process (this fear disappear with time and practice).

Therefore, techological innovations as Moodle are contributing to pedagogical innovation, leading to fundamental change in teaching methods, moving to a broader information, building new learning materials, which include links to external resources and using all Moodle features and options, while changing the 
role of the teacher from lecturer to discussion leader and moderator, adviser and consultant.

Moodle is having many benefits, which are motivating teachers to accept this challenge. Moodle is easy to learn, training for it is not difficult (it should be mentioned, that course transformation, innovative pedagogical thinking and searching for new didactical solutions within it is much more challenging, than Moodle mastering in itself). Moodle is teachers' time savig technology with it's advanced tests grading, assingnments structuring. Communication with students has been sorted, grouped, transparent, unlike e-mail chaos in the case of large number of students. Moodle is ideal for distance learning, convenient for blended learning and may be implicated step by step, in the institution's preffered pace. It is giving possibility to go from just lecturing basic material of the course to discussing the key issues and to enhance understanding and knowledge. ICT usage making teacher closer to „digital native” student and enhancing his prestige. While during the first couple of years Moodle requires more work creating e-course, developing new materials and new approaches to teaching and learning, it will pay off in the coming years, when testing and grading goes automatically, communication with the students becomes more structured, rational, transparent, learning materials aquisition enhanced and in general positive pedagogical effect appears. Moodle has another valuable features - integration with the institution's IT systems, such as e-journals, using the same login and facilitating users' management, possibility to integrate installed in institution's server Moodle start page with institution homepage, with links to related web sites, and possibility for students to get some courses from partnering educational insttitution using Moodle, thus enhancing international cooperation.

Along with number of beneficial features, one of which is possibility to monitor teaching and learning activities, some weaknesses apperar in the system, for instance, the lack of transparency at logfiles frontend. While the database server stores records of all actions made in system in continuous adding mode, without deleting anything, those records data actually can be obtained only by server administrator, if he is highly competent IT specialist. Other staff of educational institution, both managers and faculty members, should accept logfiles viewing restricted possibilities. Moodle log file tool allows teacher and non-editing teacher as well as manager to observe logfiles in three different views or sections, taken separately in each e-course:

1) Log from the past hour in Moodle 2.4 Navigation $>$ Courses $>$ My course $>$ Reports $>$ Live window (or Settings $>$ Site administration $>$ Reports $>$ Logs) for administrators and any users with this capability applied as a system role

2) Log for today in Navigation $>$ Courses $>$ My course $>$ Reports $>$ Logs

3) Log of course activities in Navigation $>$ Courses $>$ My course $>$ Reports $>$ Logs, where it is possible to run through all the dates, saving results in preferred file processing tool. 


\section{[http://docs.moodle.org/24/en/Logs\#View logs capabilities]}

From the viewpoint of educational institution administration the most useful is the third section, where it is possible to choose teacher by name, specify the period of time and to get a list of teachers activities by days and IP addresses. Log files can be saved in CSV (Comma Separated Value) format, and further analyzed in MS Excel, OpenOffice Calc, SPSS etc. This makes it possible to estimate the amount of work a teacher in communicstion with students, assignments grading and course updating.

One of the logfiles restrictions is that in the case of suspicion of interference those files in general view do not allow to see precisely the day when teacher had put the final grade to the student. But if necessary the details may found with the assistance of server administrator accessing the Moodle database directly.

At the early stage of Moodle implementation in educational institution teachers usually use Moodle as the mean of learning materials transfer in virtual environment along with some simply activities complementing traditional fulltime activities, such as forums, tests, laboratory reportsa and appointments. From the start teachers generally do not use more complicated group collaboration tools, wikis, workshops and lessons (branched courses). Even on this stage students activity monitoring could be important, but mostly in distant learning. Within blended learning there are another options. It is important to emphasize that Moodle is not implemented in higher education institutions just in order to provide learning materials for students. Even in the 1990s teachers had optional possibilities to do this by usual html site, it is still possible to do it effectively enough with Web folders as shown in Figure 2. Is is possible to use Linux Apache Web server Basic Authentication (classic. Htaccess and. Htpasswd files), alternative solution is Possible in Microsoft's IIS server with NTFS Security.

As shown, before Moodle implementation there were existing different tools allowing teacher to provide wide set of learning materials to student. The value of Moodle implementation is creation of virtual learning environment, not a ,file box", by using interactive group work tools for collaboration, knowledge enhancement, branched e-course development. All these activities do not exclude non interactive resource loading in the system. Files, books, Web pages, movies relates to $20^{\text {th }}$ century e-learning technology. The interactive virtual tools such as wikies and workshops are $21^{\text {st }}$ century technologies and it is important not to ignore them. If such activities are not used at all, it is not clear why it was needed to invest serious amount of work, if the files can be easily delivered to students without Moodle. E-learning didactic development now is at the early stage through the world of education, while first attempts to structure it's issues were made before 5-6 years (Arnold, Lermen, 2006) and there is reason to believe that Latvia is on the right way stimulating teachers to search for innovative didactical solutions in order to adopt innovative educational 
technology.

\begin{tabular}{|c|c|}
\hline \multicolumn{2}{|l|}{ Index of /ppf } \\
\hline Name & Last \\
\hline \multicolumn{2}{|l|}{ Parent Directory } \\
\hline Eaccess/ & 14-Jun- \\
\hline QBiroja_d_aut & 15-May. \\
\hline Datori_skolvadiba/ & 27-Sep- \\
\hline Datorsistemu_uzbuve/ & 15-May. \\
\hline Datortikli1/ & 15-May- \\
\hline Dinux/ & 15-May \\
\hline Lokalie_datortikli/ & 15-May \\
\hline DTT1/ & 15-May- \\
\hline ETT2/ & 16-Jun \\
\hline Dikla_opsistemas/ & $10-$ Sep \\
\hline Tikla_opsistemasIII/ & 15-May \\
\hline z_Materialu_piemeri_In & 08-Mar- \\
\hline
\end{tabular}

Figure 2. Apache Web server Basic Authentication Web folders as 20-th century e-learning resources

Typically in order to analyze "case of practice in e-learning" 18 indicators defined by B.Fetaji and M.Fetaji (2009) are used. But for institution administration wishing to conclude, how effectively e-courses are managed within e-study program, this approach is not especially suitable. At the same time no clear methodology how to achieve this aim. Present Moodle log files allow some analytical operations, bur in general these possibilities are poor. One of the reasons why this tool is not especially suitable for control function could be a worldwide problem of misunderstood democratization and liberalization while control definitely is not a priority. Even having all event record in data base, Moodle is not allowing relatively easy checking. The second reason of this situation could be increased Moodle 2.2 security, which is not allowing teacher to see users' data. In order to escape log file analysis performed outside of Moodle, we can only hope for the further work of the developer, improving the logfile tools and offering it's frontend additional options, which could be very helpful for educational institution in order to monitor e-course management effectively.

Log file analysis can give deeper results when branched Moodle e-course pattern is used, in which students can choose different activities. However, even simple e-course with the minimal requirements is a good start in e-learning, as a complement to traditional lectures. As it was mentioned, Moodle provides great 
opportunities for teacher pedagogical creativity realization. Still technically and methodologically most complete e-course development is branched e-course, in which students can open the next material only after a successful test performance with previous material. In the latest version Moodle 2.2 this didactical solutions is partly included and to some resources (file, e-book) may be applied restricted or conditioned access (see Fig. 3.)

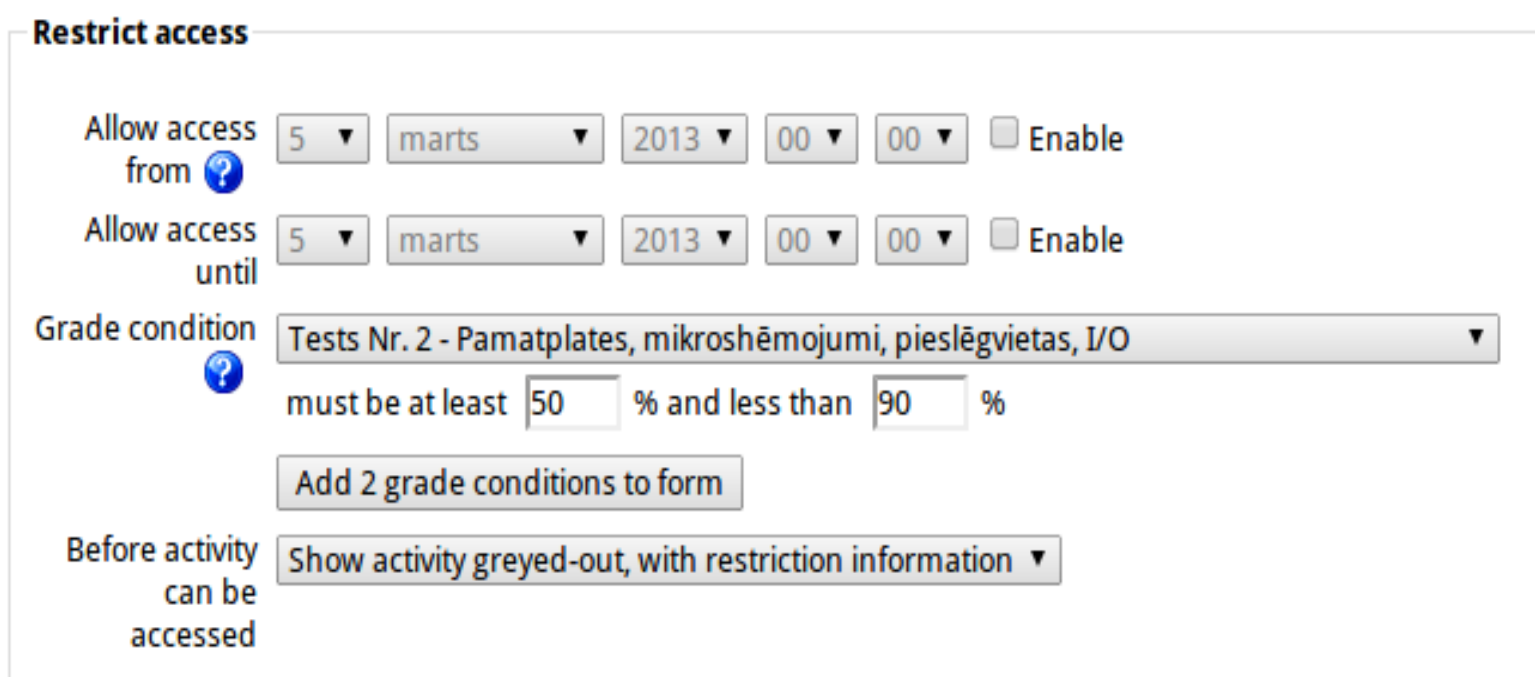

Figure 3. Restricted Access as One of Branched E-course Creation Options

Setting, shown in Figure 3., determines any grade conditions which must be met in order to access the activity. Multiple grade conditions may be set if desired. If so, the activity will only allow access when all grade conditions are met. Thus student who failed the test will be forced to return to the previous theme, and the professor will be less interest to search and to analyze log files, because the student who has got access to the final tests, apparently has mastered the course. This solution is easier for teacher then Lesson tool, but in the next versions of Moodle there will be possible to make such restrictions of conditioned access not only to single sources, but to entire theme, which will definitely reduce the number of clicks needed to create branched course.

\section{Discussion}

Change in the society leads to changes in educational system, and majority of higher education institutions in Latvia have accepted this challenge. But, probably, in the case of Moodle in Latvia technological innovation has outpaced pedagogical innovation. Such educational technology as modular object oriented virtual learning environment requires high innovative level of educational product (electronic educational materials of e-course, which is usually slightly transformed traditional course), but also a high level of innovative pedagogical 
thinking by teachers and, to some extent, high level of innovative administrative and managerial thinking by higher education institution key persons.

The previous study (Bierne, 2012) showed that clear framework needed for adoption such technological change. Students are not engaging in virtual educational interactivities, if there are no clearly defined reasons for them to do this. Teachers are not developing interactive virtual resources within their course and supporting communication and collaboration within virtual learning environment, if there are no clearly defined reasons to do this as well. Students need to have methodological background and definite guidelines from teacher to engage in using Moodle interactive tools and to participate in virtual learning activities. As study conducted by Birzina (Birzina, 2011) shoved, communication is one of the most problematic issues in course management. Discussions and course forums are extremely rarely used $(80 \%$ of respondents showed answer „never”). In $20 \%$ cases communication with lecturer had never happened. That leads to idea, that lack of interactivity in virtual educational settings may be reflecting lack of interactivity in traditional classroom as well. E-learning is providing multiple forms of communication and interaction. Birzina accents, that socialization in e-learning environment is one of the main factors which influences the effectiveness of the students e-learning (Birzina, 2011). Moodle platform includes wide range of virtual tools and options, which helps to make process of learning interactive, communicative and collaborative. Nevertheless, actualization of its interactive potential within e-learning is a serious practical challenge encountered by higher education institutions. When students and teachers interaction realizes by the means of technological tools and can be shown as a log of definite activities usage, making it traceable and measurable, it reveals gap between desirable situation and real educational practice. This is a sensitive issue, which requires a deeper investigation. In this article we have looked at only a few aspects of e-course managing, at some of MOODLE 2 options which are significant from the viewpoint of practical experience. There are also other creative solutions that can improve students' achievement and teachers' attitudes to $21^{\text {st }}$ century educational technologies.

\section{Conclusions}

1. The main pedagogical sense of Moodle data log is that it is making teaching and learning process transparent, traceable and open to monitoring, analysis, assessment and control as never before. By purposeful analysis of log data it is possible to reflect on course most and less successful elements, students' interests and difficulties, teacher responsiveness and readiness to support learning process. From the most constructive viewpoint it is useful tool for course content and teaching techniques optimization, for reflection on existing practice, revelation of the gaps between desirable and actual situation and, in general, for teacher's professional development. At the same time 
educational technology as Moodle by making teaching and learning process transparent reveals some systemic problems of pedagogical practices in higher education - lack of interactivity, lack of motivation to enhance pedagogical competence and to develop more attractive and communicative courses, narrow set of mastered didactical tool, operating with outdated content and so on.

2. These problematical aspect manifests in blended learning and distance learning in different ways. In the case of blended learning problem domination of non-interactive resources within virtual learning environment is considerable problem in itself, because students are not attending traditional lectures and seminars and in this case „box of files" and non-responsive teacher is all that they gets. Need for interaction is one of the basic pedagogical principles, and it seems obvious, that domination of noninteractive resources not helping to achieve good learning outcomes. In the case of blended learning lack of interactivity in virtual environment could be compensated by communication in traditional settings educational. Students are attending traditional lectures and seminars, but Moodle resources are mostly playing supportive and structuring role. But in case of blended learning restrained usage of even basic and non-interactive Moodle options is connected to another problem - need for teacher to restructure his course and activities in the traditional classroom. When basic course information such as synopsis and presentation is putted in Moodle, there is no need to do lecturing in traditional sense and huge room for practical skill developing activities opens in classroom. To fill this room with new content - practical and interactive, based on virtually available theoretical material, is serious challenge for teacher, who was oriented to traditional lecturing almost whole his academic life.

3. Previously published researches, as well as this study leads authors to hypothesis is that teacher usage of Moodle interactive tools is mirroring teaching practice which takes part in traditional classroom. It could be expected, that teachers who widely use interactive teaching techniques in traditional class, are willingly adopting and using Moodle interactive tools within e-course, while teachers, who minimally use interactive teaching techniques in traditional classroom, avoiding usage of interactive virtual tools. Examination of correlation between preferred teaching practices in traditional classroom and virtual learning environment among Latvian teachers in higher education institutions using Moodle could be helpful in order to clarify this hypothesis. Expected results of this future research could be significant from the viewpoint of higher education didactics and helping pedagogical innovations by creating more interactive learning environment. 


\section{Kopsavilkums}

E-kursa vadīšana analizējama gan no pedagoǵiskā viedokl̦a, ņemot vērā docētāja lomas maiṇu uz ,e-kursa vadītāju”, kas izvirza jaunas prasības viņa prasmēm, gan no administratīvā jeb institucionālā viedokḷa, kas cieši saistîts ar kursa aktivitāšu monitoringa iespējam pateicoties Moodle logfailu rīkam. Tehniska iespēja sekot sistēmas lietotāju aktivitātēm virtuālajā mācību vidē paver jaunas iespējas gan augstākas izglìtības iestādes administrācijai, vērtējot mācībspēku darbu, gan pašiem macībspēkiem produktīvi reflektējot par e-kursa norisēm un didaktiskiem risinājumiem. Raksts satur Moodle logfailu datu analīzi, kas veikta Latvijas augstākās izglīîibas iestādes nolukā apzināt to iespējas un ierobežojumus e-kursa vadīšanas pilnveidošanā. Objektivie logfailu dati tika individuāli salidzīnāti ar docētāju aptaujas datiem par Moodle vidē veicamām aktivitātēm semestra laikā. Pētījums parādīja, ka docētāji ir tendēti pārvērtēt savu aktivitāšu biežumu Moodle vidē salīdzinot ar logfailu datiem. Rakstā iezīmēts arī tālāko pētījumu virziens.

\section{Bibliography}

1. Arnold, Rolf \& Lermen, Markus (Hrsg.) (2006). eLearning-Didaktik. Grundlagen der Berufs- und Erwachsenenbuildung Herausgegeben von Dolf Arnold. Band 48. Schneider Verlag Hohengehren.

2. Bierne, Jekaterina. (2013). Actualizing Moodle Interactive Tools Usage within Distance Learning: Need for Multilevel Approach. International Journal of Information and Education Technology, Vol. 3, No. 1, 44-47.

3. Birzina, Rita. (2008). Humanistic approach within the study of adults' computer literacy. Ph.D. dissertation, Dr.Paed. University of Latvia, Riga.

4. Birzina, Rita. (2012). E-Learning for Lifelong Learning in Latvia: in ASEM White Paper E-learning for Life-Long Learning. Korea National Open University Press, Vol.II, 5-140 Retrieved February 10, 2013 from

http://priede.bf.lu.lv/grozs/Didaktika/ASEM/2 White paper.pdf

5. Fetaji, Bekim \& Fetaji, Majlinda. (2009). E-Learning Indicators: a Multi-Dimensional Model for Planning and Evaluating e-Learning Software Solutions. Electronic Journal of e-Learning Volume 7 Issue 2, 21-28 Retrieved January 9, 2013 from www.ejel.org/issue/download.html?idIssue $=11$

6. Gorbans, Imants. (2008). Decisive ICT Options in the System of Development of School Education Policy in Latvia at tge Dividing Line of the Future Digital Decade. Ph.D. dissertation, Dr. sc. administr. University of Latvia, Riga.

7. Gorbāns, Imants (2011). Latvijas skolas uz multipolāras daudzlīmen̦u IKT sabiedrības izveides sliekšnna [elektronisks resurss]. Daugavpils Universitātes 52. starptautiskās zinātniskās konferences materiāli [CD-ROM] : Daugavpils, Latvija.

8. Green, Nicole, Edwards, Helen \& Wolodko, Brenda et als. (2010) Reconceptualizing higher education. Pedagogy in Online Learning. Volume 31, Issue 3, 257-273.

9. Hollowell, Jason. (2011). Moodle as a Curriculum and Information Management System. Olton : Packt Publishing Ltd.

10. Kankevičiene, Lina. (2012). Integration of Information Society Technologies though Modernization of Higher Education Studies. Summary of Doctoral Dissertation; Social Sciences Educology (07S). Kaunas, Vytautas Magnus University. 
11. Khan, Badrul (2005). Managing E-Learning Strategies: Design, Delivery, Implementation and Evaluation. George Washington University USA. Information Science Publishing.

12. Lu, Jingyan \& Law, Nancy. (2012). Understanding Collaborative Learning Behaviour from Moodle Log Data. Interactive learning Environment, Vol.20 Issue 5, 451-466.

13. Maslo, Irina \& Fernandez-Gonzalez, Manules. (2012). The central role of educational leadership for developing students' intrapreneurship attitudes in higher education settings: a case study from Latvia. In Entrepreneurship education - a priority of higher education institutions. Eds .C.Martin, E.Druica Budapest. Retrieved January 2, 2013 from http://www.crebus.eu/images/conference/conference volume.pdf

14. Misnevs, Boriss (2010). E-learning in Latvia. Dimensions of E-Learning Education In Latvia. In Cases on challenges facing e-learning and national development: Institutional Studies and Practices. Vol. I. Turkey: Anadolu University.

15. Paulins, Nauris (2010). Moodle implementation at the Latvia University of Agriculture information technology system architecture : [ziņojums 16.starptautiskajā zinātniskajā konf. "Research for rural development 2010" Latvijas Lauksaimniecības universitātē (2010.g. 19.-21.maijs)] Research for rural development, Vol.2, 204-207.

16. Slaidiņš, Ilmārs (2005). Labas prakses rokasgrāmata e-studijās iesaistītajiem. Eiropas Estudiju Ekselences Centrs. E3Projekts - WP03. [Online]. Retrieved February 11, 2013 from http://www.pavelsjurs.lv/wp-content/uploads/2011/07/Par-talmacibu_labas-praksespiemers.pdf

17. Teachers' ICT Competences - a way to effective learning for children with hearing difficulties : learning materials (2009). Ilze Ivanova ... [et al.]] ; project coordinator, University of Latvia]; Socrates Comenius, Izglītība un kultūra ; TICTC, Teachers' ICT Competences. Riga.

18. Vronska, Natalja. (2012). Topošo skolotāju informācijas un komunikācijas tehnologiju integrēšanas prasmju attīstība mājturības un mājsaimniecības izglītībā : promocijas darbs pedagog̣ijas zinātnes nozarē augstskolas pedagog̣ijas apakšnozarē / Natalja Vronska ; zinātniskā vadītāja Elita Volāne ; Latvijas Lauksaimniecības universitāte. Tehniskā fakultāte. Izglītības un mājsaimniecības institūts. Jelgava.

\begin{tabular}{|r|l|}
\hline $\begin{array}{r}\text { Dr.sc.administr. Imants } \\
\text { Gorbāns }\end{array}$ & $\begin{array}{l}\text { University of Latvia } \\
\text { imants.gorbans@,lu.lv } \\
\text { Tel. +371 29496831 }\end{array}$ \\
\hline Mg.psych. Jekaterina & $\begin{array}{l}\text { University College of Economics } \\
\text { and Culture } \\
\text { Biekne } \\
\text { jekaterina.bierne@eka.edu.lv } \\
\text { Tel. +371 29465162 }\end{array}$ \\
\hline
\end{tabular}

